\title{
The Importance of Fecal Occult Blood in Preventive Health Services and the Concept of Chromatography
}

\section{Koruyucu Sağlık Hizmetlerinde Gaytada Gizli Kanın Önemi ve Kromatografi Kavramı}

\author{
Onur Öztürk ${ }^{* 1}$, Muhammed Emin Göktepe ${ }^{1}, \dot{I}_{z z e t}$ Fidanct $^{2}$, Muhammed Okuyucu $^{3}$
}

\begin{abstract}
Fecal occult blood (FOB) is an inexpensive, easily applicable, reliable and efficient test that is used to detect colon pathologies. FOB is applied as a screening program in family medicine practice that is a part of preventive health services in many countries. The main objective of the scanning program is to perform a FOB test at every two years for everyone between the ages 50-70 in the standards set in Turkey. The patients that are tested positive as a result of this screening which is also actively applied in Turkey are directed to secondary care for further examination by the primary care physicians. Scanning is performed by using the test kits that are based on chromatography and developed by means of immunochemical method. In this article, the importance of FOB in preventive health services and the concept of chromatography will be discussed.
\end{abstract}

Key words: Fecal occult blood, primary care, chromatography

\section{ÖZET}

Gaitada gizli kan (GGK) kolon patolojilerinin tespiti için kullanılan ucuz, uygulanabilirliği kolay, güvenilir ve kullanışlı bir testtir. GGK birçok ülkede koruyucu sağlık hizmetlerinin bir parçası olan aile hekimliği uygulamasında tarama programı olarak uygulanmaktadır. Türkiye'de belirlenen standartlarda 50-70 yaş arası herkese iki yılda bir GGK testi yapılması tarama programının ana hedefidir. Türkiye'de de aktif bir şekilde uygulanan bu tarama sonucu pozitif gelen hastaları birinci basamak hekimi ileri inceleme amacıyla ikinci basamağa yönlendirmektedir. Taramalar, temelde kromotografiye dayanan ve immünokimyasal yöntemle geliştirilen kitlerle yapılmaktadır. Bu yazıda koruyucu sağlı hizmetlerinde GGK'ın önemi ve kromatografi kavramı tartışılacaktır.

Anahtar kelimeler: Gaytada gizli kan, birinci basamak, kromatografi

Received / Geliş tarihi: 25.09.2020, Accepted / Kabul tarihi: 05.12.2020

${ }^{1 *}$ Samsun Education and Research Hospital, Department of Family Medicine, Samsun, Turkey (ORCID: 0000-0002-3371-6051)

${ }^{1}$ Samsun Education and Research Hospital, Department of Family Medicine, Samsun, Turkey (ORCID: 0000-0001-9587-4496)

${ }^{2}$ Hacettepe University, Department of Family Medicine, Ankara, Turkey (ORCID: 0000-0001-9848-8697)

${ }^{3}$ Ondokuz Mayis University, Faculty of Medicine, Department of Internal Medicine, Samsun, Turkey (ORCID: 0000-0002-6026-2024)

*Address for Correspondence / Yazışma Adresi: Onur ÖZTÜRK, M.D., Assoc. Prof. Samsun Education and Research Hospital, Department of Family Medicine, Samsun/Turkey

ORCID: 0000-0002-3371-6051

$+905547536566$

E-mail: dr.onurozturk@yahoo.com

Öztürk O, Göktepe ME, Fidanc1 İ, Okuyucu M. The Importance of Fecal Occult Blood in Preventive Health Services and the Concept of Chromatography. TJFMPC, 2021;15(1): 08-11.

DOI: $10.21763 /$ tjfmpc. 800298 


\section{Dear Editor,}

Fecal occult blood (FOB) is an easily applicable, reliable and efficient test that is used to detect colon pathologies. FOB is applied as a screening program in family medicine practice that is a part of preventive health services in many countries. Its popularity has grown in recent years. Primary care physicians play a large part in this routine screening particularly in the United States. ${ }^{1}$

\section{FOB and colon cancer}

Colon cancer is the $3^{\text {rd }}$ most frequent type of cancer in the world. It ranks $3^{\text {rd }}$ in women and $4^{\text {th }}$ in men in Turkey. The most important factor that affects the success of therapy is the stage of tumor during diagnosis. Screening makes it possible to detect the lesions that may cause this tumor at an early stage. The main objective of the scanning program is to perform a FOB test for everyone between the ages $50-70$ in the standards set in Turkey. ${ }^{2,3}$

\section{The importance in preventive health}

The patients that are tested positive as a result of this screening which is also actively applied in Turkey are directed to secondary care for further examination by the primary care physicians. ${ }^{1}$ While positive results from FOB tests bring to mind the possibility of malignancy, benign diagnoses rank first among the patients for which gastroscopy and colonoscopy are performed. ${ }^{4}$ The pathologies such as perianal diseases, inflammatory bowel diseases, polyp, and diverticulum are just a few examples to them. Half of the patients are reported to have colon pathology. Early-stage carcinoma is found in half of the patients with polyp. ${ }^{5}$ It indicates that this inexpensive and easily-applicable test leads the way in detecting the pathologies significantly.

Patients must stop using the medications for coagulation such as aspirin, warfarin, and heparin before performing FOB test. Nonsteroidal antiinflammatory drugs lead to false positive results as they impair the integrity of mucous membrane and cause minor bleeding. $2-5 \mathrm{ml}$ of bleeding a day is considered to be within normal limits. The values above these limits cause positive test results. ${ }^{6}$ It is suitable to take informed consent of a patient before testing. ${ }^{7}$ No specific diet is advised for the testing. Oral iron supplements do not bring about positive results. High dose vitamin $\mathrm{C}$ may bring about false negative results. Therefore, vitamin $\mathrm{C}$ intake should not exceed $250 \mathrm{mg} /$ day for 3 days before the testing. Monoclonal antibody test which can detect pathologies in 10 minutes is still being used in family health centers. It tests $50 \mathrm{ng} / \mathrm{ml}$ of hemoglobin in test cassette. For biochemical analysis, it is important to take samples in clean containers that don't contain any protecting agent and detergent, and preserve the samples at temperatures between $2-8^{0} \mathrm{C}$ for up to 48 hours. ${ }^{8}$ More precisely, FOB testing methods are split into 4 groups (radioactive, physical, immunochemical, and chemical methods). The first method (radioactive method) is based on the principle of radioactivity analysis of feces upon injection of intravenous radioactive substance. The second method (physical method) is the most easily applicable method and involves microscopic analysis of erythrocytes and hematin crystals in feces. The third method (immunochemical method) is more applicable than others, so it is used more frequently. Chemical method is based on the pseudo peroxidase activity of hemoglobin fraction in feces. Besides, use of latex agglutination technology enables this method to be more easy-touse. Guaiac method is the most frequently used method of the fourth method (chemical method); however, its reliability is low due to high prevalence of false positive/negative results. Foods may contain peroxidase, so a specific diet should be prescribed before application of this method. Immunochemical method is a more frequently preferred method for its high sensitivity and the use of latex agglutination technology. ${ }^{9}$

\section{Concept of chromatography}

Scanning is performed by using the test kits that are based on chromatography and developed by means of immunochemical method. Chromatography, meaning 'writing in color', was used by Mikhail Tsvet, Russian botanist, in 1906. Mikhail Tsvet carried out studies on plant pigments because of his love and curiosity for botany. He developed a decomposition method defined by the term adsorption chromatography. $\mathrm{He}$ ensured decomposition of pigments by means of ether and alcohol, and then covered the solution with calcium carbonate and realized that the pigments form colored tapes. He found two additional chlorophylls and eight additional pigments in his studies. Mikhail Tsvet defined chromatography as a result of his studies in 1903 and passed away in 1919 while he was improving his studies and the diagnosis of chronic throat infection which can be regarded as an occupational disease was reported in his death certificate. Martin and Synge improved his chromatography studies in 1942 and intended to study the basics of this method. They were awarded Nobel Prize in the field of chemistry for their theories based on the studies. Then, Martin continued his studies with another researcher, James, in 1952. Invention of gas-liquid chromatography indicates that his studies yielded good results. Purification of components was achieved by evaporating macro molecules through establishment of the theory that mobile phase can be liquid or gas and steady phase can be solid or 
liquid. Advantage of chromatography over the previous decomposition techniques is that it can be applied without the need to know the amount and structure of the chemical substances. This method enables decomposition down to the level of pictogram. Today, analysis method is required and frequently used in many fields (forensic science, petroleum industry, drug intoxication and all biochemical fields). ${ }^{10}$ Upon development of the analysis methods, these methods became easily applicable and gave quick results. Development of rapid tests was achieved through the developments in microbiology and biochemistry. Development of the immunochemical method which is the most frequently used method in FOB tests and the rapid tests by year are presented in Graphic $1 .^{10-12}$
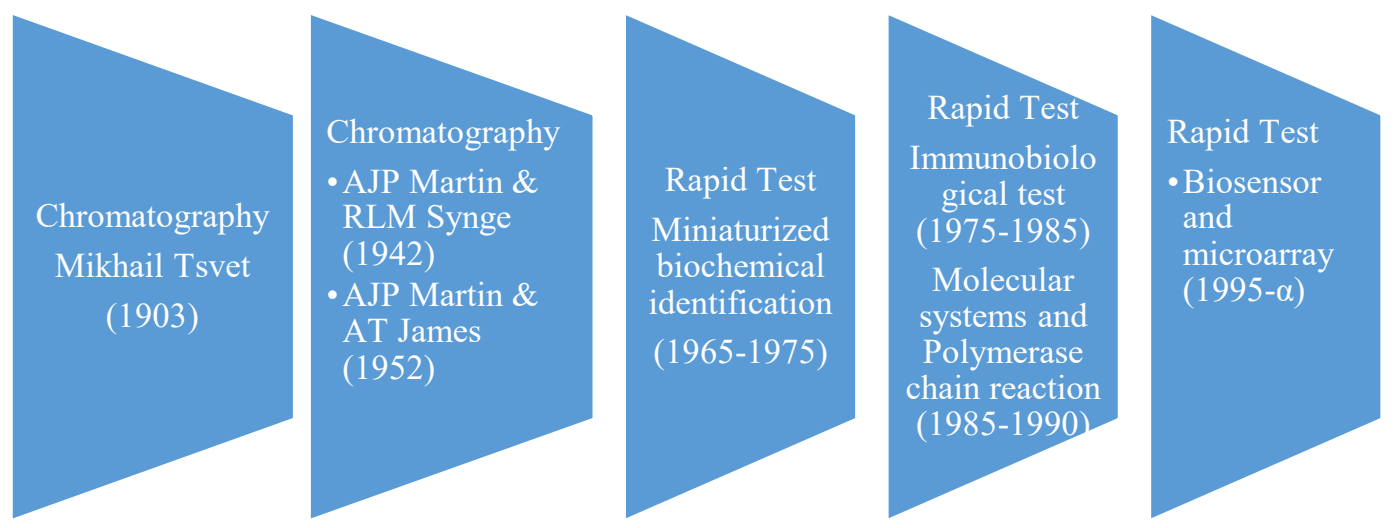

Graphic 1. Historical development chart of immunochemical method

A study that investigated the awareness level of FOB testing found that awareness level and testing rate are higher in patients with chronic diseases and the people whose first degree relatives have colon pathology. As education level increases, FOB testing rate increases, as well. ${ }^{13}$ A study that investigates the awareness level of FOB testing among health care professionals found that $21.8 \%$ of the participants do not know that scanning is performed for colon cancer and $22.5 \%$ do not know that FOB is a scanning test. ${ }^{14}$ It is evident that education and training activities and academic publications on scanning programs must be accelerated.

Reason for refusal of FOB test by the patients around the world is its cost. These tests are performed for free in the Republic of Turkey; nevertheless, some patients still refuse FOB testing. ${ }^{15}$

Family physicians should record the number of patients scanned, the number of tests performed, the number of tests not returned, the number of tests lost, and the number of tests refused for the purpose of data protection. Most of the patients want to perform the test by taking the kits to home, so the parameters such as the tests not returned or the tests lost due to incorrect testing are significant. ${ }^{7}$ Most of the patients diagnosed with cancer live in lowmiddle income countries and this number is expected to increase by $100 \%$ by 2030 . This will bring too much additional burden on healthcare expenditure. One tenth of the expenditure for global cancer treatment is made in these countries, and the expenditure on such a scale reveals the importance of the scanning programs. ${ }^{14}$

\section{Conflict of interest}

The author declares that there is no conflict of interest.

\section{REFERENCES}

1. Lin JS, Piper MA, Perdue LA, Rutter CM, Webber EM, O'Connor E, Smith N, et al. Screening for colorectal cancer: Updated evidence report and systematic review for the US preventive services task force. JAMA2016;315:2576-94.

2. T.C. Sağlık Bakanlığı Türkiye Halk Sağlı̆̆ Kurumu Kanser Daire Başkanlığı. 1. Ed. Türkiye kanser kontrol programı. 2016, pp 5058.

3. Onur O, Alper CM. Cancer early diagnosis, screening, and education centers in Turkey. Cancer Surgery 2017;02.

4. Ertuğrul İ, Sarı R, Altuntaş YE, Kaya S, Altun Ö, Uzunoğlu H, et al. Gaitada gizli kan pozitif olan taramalarda kolonoskopi ve gastroskopi sonuçlarınınanalizi. 4. Çukurova gastrointestinal cerrahi hastalıkları kongresi, 2020, Adana. 
5. Utku ÖG, Ergül B, Oğuz D. Gaitada gizli kan testi pozitifliği nedeni ile kolonoskopi yapılan hastaların kolonoskopik ve patolojik sonuçlarının değerlendirilmesi. Akademik Gastroenteroloji Dergisi2018;9:17-20.

6. Kasirga E. The importance of stool tests in diagnosis and follow-up of gastrointestinal disorders in children. Turk Pediatri Ars 2019;54:141-148.

7. Nishiwaki S, Maeda M, Yamada M, Okuno S, Harada Y, Suzuki K, et al. Clinical efficacy of fecal occult blood test and colonoscopy for dasatinib-induced hemorrhagic colitis in CML patients. Blood 2017; 129 (1): 126-128. doi: https://doi.org/10.1182/blood-2016-08-734947

8. Işiktekin Atalay B, Öztürk EG, Işikli B, Alataş İÖ, Metintaş S, Önsüz MF. İki farkli gaitada gizli kan testinin geçerlilik yönünden karşilaştirilmasi. Türk Dünyası Uygulama Ve Araştırma Merkezi Halk Sağlığı Dergisi 2018;3:15-21.

9. Altekin E, Solak A, Tuncel P. The comparison of guaiac-based and immune chemical methods for fecal occult blood screening. Türk Klinik Biyokimya Dergisi 2003;3:143-147.
10. Ettre LSMS. Tswett and the Invention of Chromatography. LCGC North America 2003;21(5):458-467.

11. Blankenfeld-Enkvist GV, Brannback M. Technological trends and needs in food diagnostics. TechnolReview 2002;132.

12. Aras Z. Rapid diagnostic methods in microbiology. TurkHij Den BiyolDerg 2011;68:97-104.

13. Öztürk EG, Atalay Işiktekin B, Önsüz MF, Zeytin AM, Küçük YS, Metintaş S. Yarı kırsal alanda yaşayan kişilerde gaitada gizli kan taraması ve tarama programları hakkında farkındalıkları. Türk Dünyası Uygulama Ve Araştırma Merkezi Halk Sağlığı Dergisi 2018;3:42-55.

14. Cantürk K, Yusuf Ü, Esra Ö, Önder A, Çiğdem Ş, Ayşe DŞ. Knowledge, attitudes and behaviors of healthworkers about cancer screenings. Ankara Medical Journal 2017;1:17.

15. Maç ÇE. Knowledge, attitudes and behaviors of geriatric people about periodic health examination. Ankara Medical Journal. 2019;19:1-9. 